\title{
RESPONS PRODUKSI TERHADAP JARAK TANAM SALAK PANGU DI DESA PANGU RAYA KECAMATAN RATAHAN TIMUR NORTH SULAWESI INDONESIA
}

\author{
Franky Reintje Tulungen \\ Vini N. Ngantung \\ Jemly Lengkong
}

Naskah diterima melalui Email agrisosioekonomi@unsrat.ac.id

: Selasa, 15 September 2020

Disetujui diterbitkan

Senin, 21 September 2020

\begin{abstract}
This study aims to obtain the plant spacing of salak-pangu on sloping land which gives high yields. This study held on January until June 2020 with survey method and data collection techniques using structured interviews with 28 salak-pangu farmers in Pangu Raya village and field observations. The samples of this study were purposively. The variables in this study were the plant spacing of salak-pangu $(X)$ and the plant production of salak pangu per hectare $(Y)$. The collected data were analyzed descriptively followed by the t-test to determine the plant spacing that gave high production. The result shows that plant spacing affects the production of salakpangu per ha. The production response forms a production function curve with the plant spacing of salak-pangu that gives the highest yields production is 1x3 meter spacing. ${ }^{* e p r m *}$
\end{abstract}

Keywords: salak-pangu, plant spacing, production

\begin{abstract}
ABSTRAK
Penelitian ini bertujuan untuk mendapatkan jarak tanam salak-pangu pada lahan miring yang memberikan hasil yang tinggi. Penelitian ini dilaksanakan pada Januari sampai Juni 2018 dengan menggunakan metode survei dan teknik pengumpulan data menggunakan wawancara terstruktur kepada 28 petani salak-pangu dan pengamatan lapangan. Sampel penelitian ini ditentukan secara sengaja (purposive sampling). Variabel dalam penelitian ini adalah jarak tanam salak-pangu (X) dan produksi tanaman salak pangu per hektare (Y). Data yang terkumpul dianalisis secara deskriptif dilanjutkan dengan uji t untuk menentukan jarak tanam yang memberikan produksi yang tinggi. Hasil penelitian menunjukan bahwa jarak tanam berpengaruh terhadap produksi salak- pangu per ha. Ini ditunjukkan oleh adanya respons produksi salak-pangu yang berbeda antara jarak tanam. Respons produksi membentuk kurva fungsi produksi dengan jarak tanam salak-pangu yang memberikan hasil paling tinggi adalah jarak tanam 1x3 meter. ${ }^{*}$ eprm*
\end{abstract}

Kata kunci: salak-pangu, jarak tanam, produksi 


\section{PENDAHULUAN}

\section{Latar Belakang}

Visi Revolusi Oranye (pembangunan buahbuahan) adalah untuk memenuhi kebutuhan konsumsi buah nasional secara mandiri dan untuk menjadikan Indonesia sebagai produsen dan eksportir terbesar buah-buahan tropis di Asia Tenggara pada tahun 2025 dan dunia pada tahun 2045. Misi dari Revolusi Oranye adalah untuk secara konsisten dan terus menerus memproduksi dan menyediakan produk buah nusantara yang berkualitas tinggi, memiliki nilai tambah dan kompetitif untuk pasar domestik dan internasional (Kementerian Pertanian, 2016). Visi Orange tersebut akan dapat diwujudkan di era industry 4.0 dan masyarakat 5.0. Keyakinan tersebut karena Indonesia memiliki potensi dasar yang besar, diantaranya adalah sumber daya alam yang amat kaya, termasuk aneka jenis buah-buahan.

Prospek pengembangan agribisnis buahbuahan (hortikultura) di Indonesia semakin cerah, baik untuk memenuhi kebutuhan ekspor maupun untuk memenuhi permintaan pasar dalam negeri. BPS (2020) menyebutkan bahwa ekspor buah Indonesia selama kurun waktu 2012-2019 mengalami peningkatan, baik dari segi jumlah, yakni 291536,9 ton pada tahun 2012 menjadi 791 673,9 ton pada tahun 2019, maupun dari segi nilai, yakni dari 168, 3415 juta dolar Amerika pada tahun 2012 menjadi 297,7817 juta dolar Amerika pada tahun 2019. Bahkan ditengah Pandemi Covid 19, periode Januari-Mei 2020, eksport buah-buah tetap mengalami pertumbuhan sebesar $31,81 \%$ dibanding dengan periode yang sama pada tahun 2019 (Anonimous, 2020).

Salah satu komoditas hortikultura yang memiliki potensi untuk dikembangkan secara komersial dan berorientasi agribisnis adalah salak (Salacca edulis). Salak merupakan jenis buah yang banyak terdapat di daerah tropis termasuk Indonesia. Buah salak dapat dimakan dalam bentuk segar maupun bentuk olahan. Kendatipun umumnya buah salak lebih banyak dimakan dalam bentuk segar.

Salak (Salacca edulis) merupakan tanaman yang tergolong dalam famili Palmae, mempunyai akar serabut dan merupakan tanaman berumah dua, dimana dalam satu pohon hanya terdapat satu bunga jantan atau betina saja. Tanaman salak umumnya dapat berbuah pada umur 3-4 tahun jika ditanam dari biji, 2-3 tahun jika ditanam dari anakan dan 1-2 tahun jika ditanam dari cangkokan. Syarat tumbuh yang dikehendaki oleh tanaman salak yaitu: (i) tanah yang gembur, banyak mengandung bahan organik, aerasi udara baik dan tidak ada genangan air dengan PH tanah antara 6-7, (ii) curah hujan ratarata antara $200-900 \mathrm{~mm} /$ bulan, (iii) ketinggian tempat antara 0-700 $\mathrm{m}$ di atas permukaan laut, (iv) suhu optimum antara 200C-300C dan (v) sinar matahari sekitar 50\%-70\% (Tjahyadi, 2012).

Di Sulawesi Utara sentra produksi buah salak adalah kabupaten Minahasa Tengara, khususnya di Desa Pangu Raya kecamatan Ratahan Timur (disamping kabupaten Sitaro). Varitas salak yang paling banyak dijumpai di daerah ini adalah varitas amboinensis (Darmadi, 2001 dalam Manurung dkk., 2013). Penanaman dan pengembagan salak di desa ini telah dilakukan oleh petani sejak penjajahan Belanda. Itulah sebabnya salak yang dihasilkan di daerah ini dikenal dengan sebutan salak pangu.

Perkebunan salak pangu telah ditetapkan pemerintah kabupaten Minahasa Tenggara sebagai kawasan Agroindustri sejak tahun 2018 (Wahongan dkk, 2015). Sebelumnya pemerintah kabupaten Minahasa Tenggara telah menetapkan buah salak pangu sebagai prioritas pengembangan buah lokal. Pembinaan petani oleh pemerintah baik dalam hal pengolahan dan pemasaran buah salak pangu telah dilakukan namun dalam hal penataan perkebunan (budidaya daya) salak pangu, seperti antara lain jarak tanam belum dilaksanakan.

Salak pangu memiliki beberapa keunggulan, yakni: (i) keunggulan komparatif, dihasilkan dari tanah yang subur dan gembur karena menjadi langganan jatuhnya abu vulkanik dari gunung api Soputan pada setiap kali meletus, (ii) keunggulan kompetitif, merupakan produk organik yang memiliki rasa yang manis, dan (iii) keunggulan strategis, letaknya yang strategis (dekat dengan kota kabupaten dan dan pusat bisnis lainnya) dan satu-satunya daerah pengahasil salak di daratan Sulawesi Utara. Di samping memiliki keunggulan tersebut, salak pangu memiliki peran penting bagi ekonomi desa Pangu Raya, yakni menjadi sumber pendapatan usahatani keluarga terbesar. Ini dapat dilihat dari kontribusi usahatani salak terhadap pendapatan usaha pertanian yang lebih besar dari $71 \%$ (Timbulus dkk, 2015). 
Meskipun usahatani salak pangu memiliki berbagai keunggulan dan menjadi sumber pendapatan terbesar dari petani di Desa Pangu Raya serta dijadikan sebagai program unggulan untuk pengembangan buah lokal dalam menunjang program Agrowisata, namun kenyataan menunjukkan bahwa petani menanam salak, khususnya jarak tanam belum mengikuti satu rekomendasi hasil penelitian yang dihasilkan di daerah setempat. Akibatnya perkebunan salak petani nampak tidak teratur dan ukuran buah salak yang bervariasi. Ukuran buah salak akan berpengaruh kepada pada harga jual. Semakin besar buah salak maka semakin tinggi pula harganya.

Hasil penelitian berkaitan dengan jarak tanam salak di Indonesia sangat minim dan di daerah penelitian belum ada. Hasil penelitian Dinas Pertanian Provinsi Yogyakarta (n.y) menyatakan bahwa jarak tanam salak pondoh pada sistem penanaman monokultur adalah $1 \times 4$ meter, $2 \times 2$ meter, 1,5 x 2,5 meter, $2 \times 4$ meter atau $3 \times 4$ meter. Jarak tanam tersebut akan lebih luas pada tanah yang subur sebaliknya pada tanah yang kritis akan lebih sempit. Penelitian di Yogyakarta tidak serta merta dapat digunakan untuk salak ppangu karena perbedaan topografi dan kesuburan tanah.

Salah satu masalah yang ditemui dalam rangka pembangunan kawasan Agrowisata dan pengembangan buah lokal tanaman salak pangu adalah belum adanya rekomendasi jarak tanam salak pangu yang memberikan hasil yang tinggi dan kualitas buah yang terbaik khusus pada tanah yang memiliki kemiringan sampai dengan 45 derajat.

\section{Rumusan Masalah}

Berdasarkan latar belakang diatas maka rumusan masalah dalam penelitian ini adalah jarak tanam salak pangu yang bagaimana yang memberikan produksi tertinggi?

\section{Tujuan Penelitian}

Tujuan dalam penelitian ini adalah untuk mendapatkan jarak tanam salak-pangu pada lahan miring yang memberikan hasil yang tinggi.

\section{Manfaat Penelitian}

Hasil penelitian ini akan sangat berguna untuk meningkatkan pendapatan petani salak pangu melalui aplikasi teknologi tepat guna budidaya salak pangu, khususnya jarak tanam yang memberikan hasil yang tinggi.

\section{METODE PENELITIAN}

\section{Waktu dan Tempat Penelitian}

Penelitian ini dilaksanakan di Desa Pangu Raya, Kecamatan Ratahan Timur pada bulan Januari sampai Juni 2018.

\section{Metode Pengumpulan Data}

Metode pengumpulan data dalam penelitian ini menggunakan metode survei dengan teknik pengumpulan data, yakni dengan cara wawancara terstruktur dan pengamatan lapangan.

\section{Metode Pengumpulan Sampel}

Populasi dalam penelitian ini adalah petani yang mengusahakan salak pangu pada lahan miring (kemiringan 50-100\%). Sampel dalam penelitian ini adalah sebagian petani salak pangu, yakni sebanyak 28 petani. Sampel ditentukan secara sengaja (purposive sampling) dengan syarat, yakni: (i) menanam salak pangu secara monokultur dengan jarak tanam tertentu dan (ii) mengusahakan salak pangu pada lahan miring, serta (iii) tidak menggunakan pupuk dan pestisida kimiawi.

\section{Konsep Pengukuran Variabel}

Variabel-variabel yang di ukur dalam penelitian ini adalah (i) jarak tanam (X) dan (ii) produksi per hectare $(\mathrm{Y})$. Jarak tanam adalah jarak antar tanaman pada saat ditanam, diukur dari atas tanaman ke bawah tanaman yang dinyatakan dalam meter dan produksi tanaman per hektare adalah produksi buah salak pangu yang dihasilkan tanaman selama satu musim panen yang dinyatakan dalam kilo gram per ha. Bahan yang dibutuhkan adalah kebun salak dan buah salak sementara alat yang dibutuhkan adalah meter, daftar pertanyaan, kamera, alat tulis, kakulator, timbangan, alat transportasi.

\section{Metode Analisis Data}

Data yang terkumpul dianalisis secara deskriptif dilanjutkan dengan uji t beda rata-rata untuk menentukan jarak tanam salak pangu yang memberikan produksi yang tinggi.

$$
t=\frac{\bar{X}_{1}-\bar{X}_{2}}{s_{X_{1} X_{2}} \cdot \sqrt{\frac{1}{n_{1}}+\frac{1}{n_{2}}}}
$$

dimana

$$
s_{X_{1} X_{2}}=\sqrt{\frac{\left(n_{1}-1\right) s_{X_{1}}^{2}+\left(n_{2}-1\right) s_{X_{2}}^{2}}{n_{1}+n_{2}-2}}
$$


Keterangan :

$\mathrm{X} 1$ = Rata-rata produksi per hektar untuk jarak tanam $1 \times 3$ meter

$\mathrm{X} 2$ = Rata-rata produksi per hektar untuk jarak tanam $2 \times 2$ meter

$\mathrm{n} 1=$ Jumlah sampel jarak tanam $1 \times 3$ meter $\mathrm{n} 2=$ Jumlah sampel jarak tanam $2 \times 2$ meter

SX1X2 = Varians gabungan (Walpole, 1992)

\section{HASIL DAN PEMBAHASAN}

\section{Gambaran Umum Tempat Penelitian}

Desa Pangu Raya adalah gabungan dari tiga desa, yakni Desa Pangu, Desa Pangu Satu dan Desa Pangu Dua. Desa Pangu Satu dan Desa Pangu Dua merupakan hasil pemekaran dari Desa Pangu pada tahun 2010. Desa ini berada sekitar $60 \mathrm{~km}$ sebelah selatan Kota Manado, Ibu Kota Provinsi Sulawesi Utara dan sekitar 6 km Sebelah Utara Kota Ratahan, Ibu Kota Kabupaten Minahasa Tenggara. Desa Pangu berbatasan langsung dengan Kabupaten Minahasa dan terletak di dataran tinggi sekitar 8 $\mathrm{km}$ sebelah timur gunung api Soputan.

Luas wilayah desa Pangu Raya (Pangu) sebesar 1447 ha dengan topografi berbukit sampai curam. Dari luas tersebut sekitar 1347 ha diperuntukan untuk lahan usaha pertanian dan sisanya sekitar 100 ha untuk pemukimaman. Desa Pangu Raya didiami oleh 609 kepala keluarga (KK) dimana 86,04\% dari antaranya adalah keluarga petani. Bahkan di Desa Pangu 95,59\% keluarga adalah keluarga petani. Dari jumlah petani tersebut hampir semua petani memiliki dan mengusahakan salak pangu.

Tanaman yang diusahakan atau ditanam oleh petani di Desa Pangu Raya sebagian besar adalah salak, kemudian diikuti oleh tanaman kelapa, pisang dan enau. Disamping itu ditemukan pula tanaman lainnya, seperti jagung, cabe, tomat dan padi. Cara penaman salak oleh petani bervariasi, yakni dengan sistem monokultur dan polikultur. Pada sistem polikultur tanaman salak biasanya ditanam di antara tanaman kelapa dan tanaman lainnya.

Tanaman salak pangu banyak ditanam oleh petani atau penduduk sebagai tanaman konservasi. Tanaman salak pangu yang ditanam $1 \mathrm{x} 3 \mathrm{~m}$ yang mengikuti kountur tanah membentuk teras bangku. Pelepak yang dibersihkan dari tanaman salak pangu diletakkan horisontal tegak lurus dengan arah kemiringan tanah sehingga dapat menahan pengikisan tanah oleh air (run off) dari atas ke bawah. (gambaran umum tempat penelitian dapat dilihat pada Tabel 1).

Tabel 1. Luas Wilayah, Jumlah Kepala Keluarga dan Keluarga Petani Tempat Penelitian, 2018

\begin{tabular}{llccc}
\hline No & Desa & Luas (ha) & Jumlah KK & $\begin{array}{c}\text { Jumlah } \\
\text { Keluarga Petani }\end{array}$ \\
\hline 1 & Pangu & 589 & 204 & $195(95,59)$ \\
2 & Pangu Satu & 431 & 210 & $155(73,81)$ \\
3 & Pangu Dua & 427 & 195 & $174(89,23)$ \\
\hline \multicolumn{2}{l}{ Jumlah } & 1447 & 609 & $524(86,04)$ \\
\hline
\end{tabular}

Sumber: Monografi desa 2018

\section{Gambaran Umum Responden Petani Salak di Desa Pangu}

Responden berdasarkan umur dapat ditunjukkan bahwa sebagian besar petani responden berusia produktif, yakni 78,57\% dan sisanya sebanyak $21,43 \%$ tergolong lanjut usia. Umur responden dapat dilihat pada Tabel 2.

Tabel 2. Tingkat umur reponden petani salak di Desa Pangu, 2018

\begin{tabular}{|c|c|c|c|c|}
\hline No & $\begin{array}{l}\text { Tingkat } \\
\text { (Tahun) }\end{array}$ & Umur & $\begin{array}{c}\text { Jumlah } \\
\text { Petani }\end{array}$ & Persentase \\
\hline 1 & $\leq 30$ & & 2 & 7,14 \\
\hline 2 & $31-59$ tahun & & 20 & 71,43 \\
\hline 3 & $\geq 60$ tahun & & 6 & 21,43 \\
\hline & Total & & 28 & 100 \\
\hline
\end{tabular}

Sumber: diolah dari hasil wawancara 2018

Tabel 2 menunjukkan bahwa umur tertinggi petani salak pangu adalah 72 tahun dan umur petani salak pangu termuda adalah 29 tahun dengan rata-rata umur responden 50,6 tahun. Ini memberi indikasi bahwa petani salak panguk di Desa Pangu Raya memiliki potensi untuk berkembang. Artinya dengan sentuhan teknologi budidaya, panen dan pemasaran akan dapat meningkatkan pendapatan petani salak pangu organik.

Responden berdasarkan tingkat pendidikan sebanyak $14 \quad(50 \%)$ petani berpendidikan SMA kemudian diikuti oleh mereka yang berpendidikan SMP sebanyak 10 $(35,71 \%)$ petani, SD sebanyak $2(7,14 \%)$ dan perguruan tinggi sebanyak $2(7,14 \%)$ petani. Ini berarti lebih dari separuh petani salak pangu $(57,14 \%)$ berpendidikan SMA ke atas. Pendidikan responden dapat dilihat pada Tabel 3. 
Tabel 3. Keadaan Tingkat Pendidikan Responden Petani Salak Di Desa Pangu, 2018

\begin{tabular}{llcr}
\hline No & Pendidikan & Jumlah Petani & Persentase \\
\hline 1 & SD & 3 & 10,71 \\
2 & SMP & 9 & 32,14 \\
3 & SMA & 14 & 50 \\
4 & PT & 2 & 7,14 \\
\hline & Total & 28 & 100 \\
\hline
\end{tabular}

Sumber: diolah dari hasil wawancara 2018

Responden berdasarkan luas penguasahan lahan untuk tanaman salak bahwa petani yang mengusahakan tanah paling luas adalah sebesar 2,5 ha dan petani yang mengusahan lahan paling sempit adalah seluas 0,2 ha dengan rata-rata luas pengusahaan lahan adalah 0,8 ha per petani. Selanjutnya dilihat dari luas penguasaan tanah dapat ditunjukkan bahwa lebih dari separuh petani $(53,57 \%)$ menguasai lahan sama dengan atau lebih kecil 0,5 ha dan hanya $10,71 \%$ petani yang menguasai lahan lebih besar dari 1 ha. Penguasahan lahan responden dapat dilihat pada Tabel 4.

Tabel 4. Luas Penguasaan Tanah Responden Petani Salak di Pesa Pangu, 2018

\begin{tabular}{llcr}
\hline No & $\begin{array}{c}\text { Luas Penguasaan } \\
\text { Tanah }\end{array}$ & Jumlah Petani & Persentase \\
\hline 1 & $\leq 0,5$ ha & 15 & 53,57 \\
2 & $0,6-1,0$ ha & 10 & 35,71 \\
3 & $\geq 1$ ha & 3 & 10,71 \\
\hline & Total & 28 & \\
\hline
\end{tabular}

Sumber: diolah dari hasil wawancara 2018

Responden berdasarkan status penguasaan tanah dapat ditunjukkan bahwa sebagian besar petani menguasai tanah dengan status milik sendiri dan hanya sebagian kecil $(7,14 \%)$ dari petani yang menguasai tanah dengan status penggarap atau bagi hasil. Status penguasahaan tanah dapat dilihat pada Tabel 5.

\begin{tabular}{|c|c|c|c|}
\hline No & $\begin{array}{l}\text { Status } \\
\text { Penguasaan } \\
\text { Tanah } \\
\end{array}$ & Jumlah Petani & Persentase \\
\hline 1 & Penggarap & 2 & 7,14 \\
\hline 2 & Pemilik & 26 & 92,86 \\
\hline & Total & 28 & 100 \\
\hline
\end{tabular}

Sumber: diolah dari hasil wawancara 2018
Responden berdasarkan jarak tanam tanaman salak terdiri dari jumlah terbanyak petani $(42,86 \%)$ menggunakan jarak tanam 1 x 3 $\mathrm{m}$ diikuti oleh jarak tanam $2 \times 2 \mathrm{~m}$ sebanyak $28,57 \%$ dan jarak tanam $2 \times 3$ m sebanyak $10,71 \%$. Jarak tanam responden dapat dilihat pada Tabel 6.

Tabel 6. Keadaan Jarak Tanam Salak Responden Petani Salak di Desa Pangu, 2018

\begin{tabular}{llcr}
\hline No & Jarak Tanam & Jumlah Petani & Persentase \\
\hline 1 & $1 \times 2 \mathrm{~m}\left(2 \mathrm{~m}^{2}\right)$ & 2 & 7,14 \\
2 & $1 \times 3 \mathrm{~m}\left(3 \mathrm{~m}^{2}\right)$ & 12 & 42,86 \\
3 & $2 \times 2 \mathrm{~m}\left(4 \mathrm{~m}^{2}\right)$ & 8 & 28,57 \\
4 & $1,5 \times 3 \mathrm{~m}\left(4,5 \mathrm{~m}^{2}\right)$ & 1 & 3,57 \\
5 & $1,5 \times 4 \mathrm{~m}\left(6 \mathrm{~m}^{2}\right)$ & 1 & 3,57 \\
6 & $2 \times 3 \mathrm{~m}\left(6 \mathrm{~m}^{2}\right)$ & 3 & 10,71 \\
\hline & Total & 28 & 100 \\
\hline
\end{tabular}

Sumber: diolah dari hasil wawancara 2018

Responden berdasarkan jenis salak pangu yang diusahakan oleh petani bervariasi, yakni: (i) yang memiliki buah berbentuk bulat dan (b) yang memiliki buah yang berbentuk lonjong. Dari kedua jenis salak yang ada, jenis salak yang paling banyak diusahakan petani adalah salak yang memiliki buah bulat (50\%) ini disebabkan oleh karena buah yang berbentuk bulat rasanya lebih manis dari yang berbentuk lonjong. Jenis salak pangu dapat dilihat pada Tabel 7.

Tabel 7. Jenis Salak Yang Diusahakan Responden Petani Salak di Desa Pangu, 2018

\begin{tabular}{llcr}
\hline No & Jenis Salak & Jumlah Petani & Persentase \\
\hline 1 & Bulat & 14 & 50,0 \\
2 & Lonjong & 6 & 21,43 \\
3 & Bulat dan Lonjong & 4 & 14,27 \\
4 & Campuran & 4 & 14,27 \\
\hline & Total & 28 & 100
\end{tabular}

Sumber: diolah dari hasil wawancara 2018

Responden berdasarkan produksi salak pangu tertinggi adalah $5 \mathrm{~kg}$ per tanaman dan terendah seberat $1 \mathrm{~kg}$ per tanaman dengan ratarata produksi 3,4 kg per tanaman. Jika dikonversi ke hektare, maka dapat ditunjukkan bahwa produksi tertinggi $13333 \mathrm{~kg}$ per ha, dan produksi terendah $5000 \mathrm{~kg}$ per ha dengan rata-rata produksi $8269 \mathrm{~kg}$ per ha. 
Selanjutnya jika produksi salak pangu dikategorikan menurut produksi per ha, maka dapat ditunjukkan bahwa sebagian besar petani salak pangu memiliki produksi salak per ha antara 5-10 ton. Jika harga per kg Rp 5000 maka pendapatan petani salak berkisar antara $\mathrm{Rp} 25$ juta sampai dengan Rp 50 juta per hektar. Jumlah produksi salak pangu dapat dilihat pada Tabel 8 .

Tabel 8. Produksi Per Hektare Salak Responden Petani Salak di Desa Pangu, 2018

\begin{tabular}{llcr}
\hline No & $\begin{array}{l}\text { Produksi } \\
\text { hektare (Ton) }\end{array}$ & Jumlah Petani & Persentase \\
\hline 1 & $\leq 5,0$ Ton & 4 & 14,27 \\
2 & $5,1-9,9$ Ton & 20 & 71,43 \\
3 & $\geq 10,0$ Ton & 4 & 14,27 \\
\hline & Total & 28 & 100 \\
\hline
\end{tabular}

Sumber: diolah dari hasil wawancara 2018

\section{Respons Produksi terhadap Jarak Tanam Salak Pangu}

Berdasarkan hasil penelitian yang dilakukan melalui analisis deskriptif jarak tanam salak pangu dapat dikelompokkan dalam 4 (empat) kelompok, yakni jarak tanam 1x2 m, 1x3 m, $2 \times 2$ m dan $3 \times 4$ meter. Berdasarkan kelompok atau kategori tersebut maka diperoleh rata-rata produksi untuk jarak tanam $1 \times 2$ sebanyak 6250 kg per ha, jarak tanam $1 \times 3$ m sebanyak $9305 \mathrm{~kg}$ per ha, jarak tanam $2 \times 2 \mathrm{~m}$ per ha sebanyak 7778 kg per ha dan jarak tanam 2x3 m sebanyak 6667 $\mathrm{kg}$ per ha. Jarak tanam salak pangu yang responsif atau memberikan produksi per hektare paling baik adalah jarak tanam adalah jarak tanam $1 \times 3$ m kemudian diikuti jarak tanam $2 \times 2$ $\mathrm{m}$ (Gambar 1).

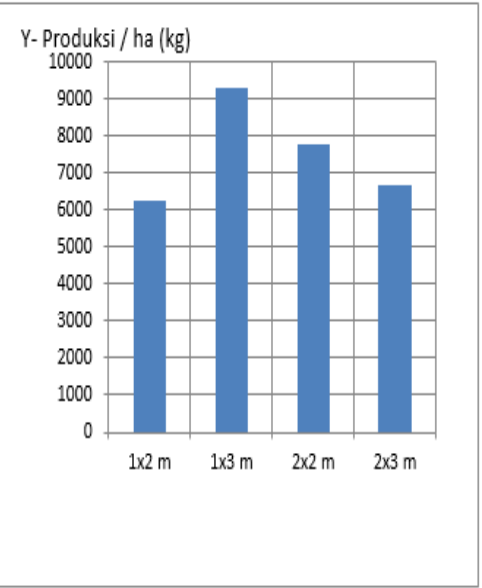

Gambar 1. Respons Produksi Terhadap Jarak Tanam Salak Pangu di Desa Pangu, 2018
Tetapi terdapat perbedaan hasil rata-rata produksi per ha salak pangu yang menyolok antara jarak tanam, namum hasil ini belum dapat dibuktikan secara statistik. Ini ditunjukkan oleh, antara lain uji beda rata-rata untuk jarak tanam $1 \times 3 \mathrm{~m}$ dan $2 \times 2 \mathrm{~m}, \mathrm{t}$ hitung $=1,40$. Sementara $\mathrm{t}$ tabel pada tingkat kepercayaan $99 \% \quad(\alpha=0,01)$ derajat bebas 19 adalah 2,093. Tidak signifikannya uji tersebut disebabkan oleh antara lain kurangnya petani yang menjadi sampel pengamatan.

Jarak tanam yang terlalu sempit (1x2) tidak memberikan hasil yang tinggi. Ini dikarenakan oleh adanya perbedaan lingkungan dengan jarak tanam yang lebih luas. Pada jarak tanam sempit ini terjadi persaingan cahaya matahari dan unsur hara yang tersedia dalam tanah. Pada jarak tanam yang terlalu luas $(2 \times 3 \mathrm{~m})$ lingkungan yang ada dapat memberikan produksi pertanaman yang lebih baik tetapi tidak untuk produksi per hektare.

Hasil analisis deskriptif menunjukkan bahwa terdapat kecenderungan produksi buah salak pangu terhadap jarak tanam mengikuti fungsi produksi, yakni $\mathrm{Y}=\mathrm{f}(\mathrm{Xi})$. Pada jarak tanam yang terlalu rapat tanaman salak memberikan hasil produksi yang rendah kemudian meningkat sering dengan bertambahnya jarak tanam. Peningkatan produksi ini terus meningkat sampai pada titik maksimun menurun seiring dengan bertambahnya jarak tanam (Gamber 1). Pertumbuhan dan produksi tanaman salak $(\mathrm{P}=$ performance $)$ dipengaruhi oleh dua faktor, yaitu genetika ( $\mathrm{G}=$ genetika $)$ ) dan lingkungan ( $\mathrm{E}=$ environtment) tempat tumbuhnya (Griffiths et al., 2000). Kedua factor ini harus berada dalam kondisi yang optimum untuk mendapatkan produksi yang tinggi $(P=G+E)$. Bila salah satu dari kedua faktor tersebut tidak optimum, maka pertumbuhan dan hasil tanaman tidak akan maksimum.

Faktor genetika terkait dengan keanekaragaman hayati (biodiversity). Semakin tinggi keanekaragaman hayati maka semakin berlimpah pula sumber pilihan yang tersedia (Mardiastuti, 1999). Hasil pengamatan dapat ditunjukkan bahwa salak pangu memiliki banyak keanekaragaman. Ini ditunjukkan oleh bentuk buah salak dan rasa buah salak yang bervariasi. Buah salak yang berbentuk bulat memiliki rasa yang relatif lebih manis dibanding dengan bentuk 
buah lainnya. Disamping itu faktor genetik tanaman berpengauh terhadap produksi buah salak pangu. Artinya varitas yang berbeda akan merespons jarak tanam juga berbeda yang pada akhirnya menghasilkan produksi yang berbeda pula.

Faktor alam dapat dimanipulasi dengan menciptakan lingkungan yang sesuai dengan kebutuhan tanaman, baik untuk unsur hara maupun iklim mikro. Unsur hara di perkenunan pangu tersedia dalam jumlah yang cukup. Persoalannya adalah bangaimana mempertahan kan unsusr hara tersebut agar tetap tersedia bagi tanaman. Iklim mikro dapat direkayasa dengan pengaturan jarak tanam. Jarak tanam yang optimal akan dapat menciptakan iklim mikro yang dibutuhkan tanaman.

Keberadaan faktor genetika dalam fungsi nya terhadap fenotipe tanaman adalah tunggal, yaitu hanya susunan gennya yang ada pada tanaman tersebut saja.Tidak lebih dan tidak kurang. Sebaliknya, keberadaan faktor lingkungan adalah jamak. Faktor lingkungan ini bisa berupa lingkungan biotik dan juga lingkungan abiotik. Lingkungan biotik bisa berupa hama, penyakit, dan gulma. Lingkungan abiotik dapat dibagi menjadi iklim mikro dan kondisi tanah (media tumbuh tanaman). Encyclopedia Britannica (2012), Cahaya matahari atau radiasi surya merupakan unsur iklim utama berpengaruh langsung terhadap perubahan unsur iklim mikro lainnya yang selanjutnya berpengaruh terhadap produksi buah salak pangu (Indrawan dkk., 2017).

Berkaitan dengan pemeliharaan tanaman dalam hal ini pembersihan gulma dan pemangkasan daun serta pemanenan buah, jarak tanam $1 \times 3 \mathrm{~m}$ dan $2 \times 3$ meter lebih praktis dan mudah dibanding dengan jarak tanam $2 \times 2$ meter karena ada ruang yang cukup untuk melakukan pemanenan dan pembersihan. Kepraktisan dan kemudahan dalam pemeliharaan dan pemanenan salak pangu dapat mengurangi biaya pemeliharaan dan pemanenan.

Berkaitan dengan pemeliharaan kesuburan tanah, penanaman dengan jarak tanam $1 \times 3$ meter (jarak antar tanaman lebih rapat) dengan jarak antar barisan tanaman lebih lebar dan ditanaman menurut kontur tanah dapat mengurangi run-off atau pengikisan tanah oleh air hujan sehingga bahan organik yang kaya akan unsur hara tidak tercuci oleh air atau dapat dipertahankan. Pada kondisi ini salak pangu yang ditanam menurut kontur akan memiliki fungsi bukan saja produksi tetapi juga konservasi. Fungsi konservasi tanaman salak terjadi ketika akar tanaman salak pada lajur antar tanaman (jarak 1(satu) meter) ini saling mengikat sehingga tanah terikat oleh akar secara baik. Itulah sebabnya sekalipun kemiringan tanah sampai dengan $100 \%$ tetapi teras-teras bangku tetap kokoh.

Selanjutnya, dari segi pemandangan, tanaman salak pangu yang ditanam dengan jarak antar barisan tanaman kurang dari tiga meter, misalnya untuk jarak tanam $1 \times 2$ meter atau $2 \times 2$ meter kelihatan kurang baik dilihat dari segi estetika. Perkebunanannya Nampak tidak teratur, sulit dibersikan dan sulit dilalui oleh manusia.

Meskipun produksi per hektare pada jarak tanam $2 \times 2$ meter lebih tinggi dari jarak tanam $2 \times 3$ meter, namun dari segi kualitas buah jarak tanam 1x3 meter dan $2 \times 3$ meter memberikan hasil yang lebih baik, yakni ukuran buahnya lebih besar. Hal ini karena pada jarak tanam 2x2 meter tidak ada ruang bagi petani untuk melakukan pembersihan tanaman sehingga buah yang dihasilkan relatif lebih kecil.

Penetapan rekomendasi jarak tanam hendaknya perlu didasarkan pada alasan keuntungan dan kepraktisan disamping dapat memecahkan masalah yang dihadapi petani. Artinya hasil penelitian itu harus dipahami dengan saksama (berdasarkan pertimbangan teknis, ekonomi, sosial, budaya dan lingkungan) untuk menghasilkan atau menciptakan inovasi atau intelijen (Tulungen et al. 2020 dan Tulungen, 2019). Suatu inovasi yang ditawarkan harus memenuhi syarat lebih mudah dilaksanakan dan lebih menguntungkan petani baik dari segi ekonomi dan keindahan dan kelestarian lingkungan.

\section{KESIMPULAN DAN SARAN}

\section{Kesimpulan}

Jarak tanam berpengaruh terhadap produksi salak pangu per ha. Ini ditunjukkan oleh adanya respons produksi salak pangu di desa Pangu yang berbeda relatif diantara jarak tanam. Jarak tanam salak pangu yang memberikan produksi salak per ha paling baik adalah jarak tanam 1x3 m. 


\section{Saran}

Perlu dilakukan penelitan lebih lanjut untuk mengetahui: (i) jarak tanam yang memberikan kualitas buah yang baik (ukurannya atau grade-nya), (ii) jarak tanam yang dapat menunjang konservasi tanah dan air, (iii) jarak tanam yang memberikan pendapatan optimal bagi usahatani salak pangu, dan (iv) jarak tanam yang dapat menunjang program agrowisata salak pangu organik.

\section{DAFTAR PUSTAKA}

Anonimous 2020. Hingga Mei 2020, Ekspor Pertanian Saja yang Tumbuh Positif. Berita Satu. https://www.beritasatu. com/elvira-anna-siahaan/ekonomi/ 645 237/hingga-mei-2020-ekspor-pertaniansaja-yang-tumbuh-positif.

BPS 2020. Ekspor Buah-Buahan Tahunan menurut Negara Tujuan Utama, 20122019.https://www.bps.go.id/statictable/2 019/02/18/2020/ekspor-buah-buahan tahunan-menurut-negara-tujuanutama 2012-2019. html diunduh 1 Agustus 2020.

Dinas Pertanian Provinsi Yogyakarta (n.y). Salak Salacca edulis). https://distan .jogjaprov.go.id/wpcontent/download/b uah/salak.pdf diakses 15 Juli 2020.

Griffiths, A.J.F., Miller J.H., Suzuki, D.T., et al. 2000. An Introduction to Genetic Analysis. 7th edition. New York: W. H. Freeman.https://www.ncbi.nlm.nih.gov/ books/NBK21866/ diakses 15 Mei 2020.

Kementerian Pertanian 2016. Fruit Indonesia 2016: Kekayaan Buah Tropis Nusantara dari Indonesia untuk Dunia. https://www.pertanian.go.id/home/?sho $\mathrm{w}=$ news\&act=view\&id $=1838$.
Manurung, V.H., Djarkasi, G.S.S., Langi, T. M., dan Lalujan, L.E. 2013. Analisis Sifat Fisik dan Kimia Buah Salak Pangu (Salacca zalacca) dengan Pelilinan Selama Penyimpanan. Ejournal UNSRAT, Cocos. Volume 3 No 5.

Mardiastuti, Ani 1999. Keanekaragaman Hayati: Kondisi dan Permasalahannya. Bogor: Fakultas Kehutanan IPB. http://ani _mardiastuti.staff.ipb.ac.id/files/2011/0 9/KEHATI-DAN-PERMASALAHAN NYA.pdf diakses 15 Juli 2020.

Timbulus, C.S., Sendow, M.M., Katiandagho, Th.M. dan Timban, J.F.J. 2015. Kontribusi Pendapatan Keluarga Petani di Wilayah Desa Pangu Kecamatan Ratahan Timur. Cocos. Volume 6 Nomor 9 Tahun 2015. Hal 113. http://garuda.ristekbrin. go.id/ jour $\mathrm{nal} / \mathrm{view} / 1027$ ?issue $=\mathrm{Vol} \% 206, \% 20 \mathrm{~N}$ o\%209\%20(2015).

Tulungen, F.R. 2019. Cengkeh dan Manfaatnya bagi Kesehatan Manusia melalui Pendekatan Competitive Intelligence. Jurnal Biofarmasetikal Tropis. Volume 2 Nomor 2, 158-169.

Tulungen, F.R., Lengkong, J., Karuntu, P.E., Oping, Y.M. dan Rumondor, F.S.J. 2020. Program Strategi untuk Meningkatan Keuntungan Usahatani Cengkeh Berdasarkan Analisis Struktur Biaya di Minahasa, Sulawesi Utara. Frontiers: Jurnal Sains dan Teknologi. Volume 3 Nomor 1, hal. 19-25.

Walpole, R. E. 1992. Pengantar Statistika. Jakarta: Gramedia. 